\title{
Correlation between sarcopenia and nailfold microcirculation, serum 25-hydroxycholecalciferol (vitamin D3) and IL-17 levels in female patients with rheumatoid arthritis
}

\author{
Lei Zhang ${ }^{\mathrm{a}}$, Dongmei Mao ${ }^{\mathrm{b}}$, Qi Zhang ${ }^{\mathrm{a}}$
}

\begin{abstract}
Aims. To investigate the correlation between sarcopenia and nailfold microcirculation and serum 25-hydroxycholecalciferol [25 (OH) D3] (instead of 25-hydroxyvitamin D) and IL-17 levels in female rheumatoid arthritis (RA) patients. Methods. 130 female rheumatoid arthritis (RA) patients and 80 healthy controls were tested. Nailfold capillaroscopic scores (NFCS) were measured. Bioimpedance analysis (BIA) was used to measure skeletal muscle mass. Enzyme-linked immunosorbant assay (ELISA) was used to detect the levels of IL-17, IL-6 and TNF-a. Serum 25 (OH) D3 concentration was determined by photochemical immunoassay. The correlation was analyzed by Pearson's correlation, and the influencing factors were analyzed by binary logistic regression.

Results. (1) Compared with the control group, NFCS and serum IL-17 levels were higher in the RA group, while the serum $25(\mathrm{OH}) \mathrm{D} 3$ and skeletal mass index (SMI) were lower. (2) Pearson correlation analysis found: SMI was positively correlated with $25(\mathrm{OH})$ D3 $(r=0.515, P<0.001)$, SMI was negatively correlated with IL-17 $(r=-0.468, P<0.001)$, SMI was negatively correlated with NFS ( $r=-0.229, P=0.009)$; (3) Logistic regression analysis: serum $25(\mathrm{OH}) \mathrm{D} 3$ was a protective factor for sarcopenia $(\mathrm{OR}=0.392, P=0.016) ; \mathrm{IL}-17, \mathrm{C}$-reactive protein, and NFS were risk factors for sarcopenia $(\mathrm{OR}=1.516$, $P=0.049 ; \mathrm{OR}=1.469, P=0.045 ; \mathrm{OR}=3.497, P=0.002$ ).

Conclusion. Secondary sarcopenia in RA is common and is closely related to microcirculation abnormalities. Increased NFCS is a risk factor for sarcopenia. Decreased serum $25(\mathrm{OH})$ D3 levels and increased IL-17 are also risk factors for sarcopenia, but the mechanisms involved in sarcopenia and microcirculation abnormalities need further investigation.
\end{abstract}

Key words: sarcopenia, arthritis, rheumatoid arthritis, nailfold microcirculation, 25-hydroxycholecalciferol, interleukin 17, correlation study

Received: February 22, 2020; Revised: July 6, 2020; Accepted: August 20, 2020; Available online: September 17, 2020

https://doi.org/10.5507/bp.2020.036

(c) 2021 The Authors; https://creativecommons.org/licenses/by/4.0/

${ }^{a}$ Department of Rheumatology and Immunology, Shengli Oilfield Central Hospital No. 31, Jinan Road, Dongying 257034, Shandong, China 'Department of Cardiology, Shengli Oilfield Central Hospital, No. 31, Jinan Road, Dongying 257034, Shandong, China Corresponding author: Lei Zhang, e-mail:golddot@vip.163.com

\section{INTRODUCTION}

Sarcopenia is a syndrome in which skeletal muscle volume loss and decreased strength are accompanied by physical dysfunction. A variety of factors and mechanisms including chronic inflammation are involved in its occurrence. Rheumatoid arthritis (RA) is a common chronic inflammatory rheumatism in which serum interleukin 1 (IL-1), interleukin 6 (IL-6), and interleukin 17 (IL-17), tumor necrosis factor alpha (TNF- $\alpha$ ) and other pro-inflammatory factors are increased. With the development of the disease, patients have varying degrees of joint damage, musculoskeletal damage, decreased balance, increased fracture risk and mortality ${ }^{1}$, and, at the same time, sarcopenia significantly increases the risk of osteoporo$\mathrm{sis}^{2}$. Research shows that microcirculation abnormalities occur in RA patients, which causes ischemic hypoxia in bone tissues, the gastrointestinal tract, kidneys, gonads and other organs closely related to bone metabolism, resulting in poor calcium absorption and transportation ${ }^{3}$. Production and release of estrogen, testosterone, 1, 25
$(\mathrm{OH}) 2 \mathrm{D} 3$ are reduced, which affects calcium salt absorption, and promotes and aggravates osteoporosis.

Nailfold microcirculation abnormalities are closely related to disease activity and osteoporosis, but whether they are also involved in the occurrence and development of sarcopenia has not been reported. In view of this, we conducted this study to preliminarily explore the correlation between sarcopenia, nailfold microcirculation and related cytokines, to provide help for further research in the future.

\section{PATIENTS AND METHODS}

\section{Patients}

A total of 130 female RA patients admitted to the Department of Rheumatology and Immunology of Shengli Oilfield Central Hospital from January 2018 to December 2019 were recruited. The duration of disease was ( 11.83 \pm 6.82 ) months, and the total time of steroid therapy was $\leq 3$ months. Patients met the Rheumatology Association's 
classification criteria for RA (ref. ${ }^{4}$ ), and were aged 22-71 years, with a mean of $45.37 \pm 9.84$ years. Patients' disease course, height, weight, disease activity, steroid use and laboratory tests such as erythrocyte sedimentation rate (ESR), C-reactive protein (CRP), anti-CCP antibody (ACPA) titer were recorded in details. The visual analogue scale (VAS)-related general health assessment (GH), and the swollen joint count (SJC 28) and the tenderness joint count (TJC 28) among 28 joints (including bilateral wrist joints, metacarpophalangeal joints, proximal interphalangeal joints, shoulder joints, elbow joints and knee joints, etc.) of RA patients were recorded. The DAS 28 was calculated according to the formula [DAS $28(\mathrm{CRP})=0.56 \times$ $+0.28 \times+0.014 \mathrm{GH}+0.36 \times \operatorname{In}(\mathrm{CRP}+1)+0.96]$.

Exclusion criteria: severe liver, kidney, and heart dysfunction; active infection; neoplastic disease; diabetes; hand trauma; long-term history of smoking or drinking; systemic use of high-dose steroids. The 80 age- and gendermatched controls were from the health examination center of our hospital. This study was reviewed and approved by the ethics committee of our hospital, and signed written informed consent was obtained from all subjects.

\section{Sarcopenia detection and definition}

Korean InBody720 body composition analyzer (8-point contact electrode, measuring impedance range 100-950 $\Omega$ ) was used. Multi-frequency bioimpedance analysis (BIA) was used to measure various indicators such as skeletal muscle mass. Skeletal muscle mass corrected by body mass [limb muscle mass $(\mathrm{kg}) /$ height 2 $\left.\left(\mathrm{m}^{2}\right)\right]$, and skeletal mass index [SMI] were used as reference indicators. Diagnostic criteria of sarcopenia: The body mass corrected skeletal mass index (SMI), where $\mathrm{SMI}=$ Appendicular skeletal muscle mass $(\mathrm{ASM})(\mathrm{kg}) /$ height $^{2}\left(\mathrm{~m}^{2}\right)$, is used as the reference index. The patient is diagnosed as sarcopenia if his or her SMI is more than 1 standard deviation below the mean SMI of the young references of the same age, sex and ethnic group. Specific diagnostic thresholds were based on recommendations of the Asian Sarcopenia Working Group ${ }^{5}: 7.0 \mathrm{~kg} / \mathrm{m}^{2}$ for men and $5.7 \mathrm{~kg} / \mathrm{m}^{2}$ for women.

\section{Nailfold microcirculation assessment}

\section{Definition of nailfold microcirculation morphology}

With reference to Ingegnoli et al. ${ }^{6}$, capillary density was defined as the number of capillaries within $1 \mathrm{~mm}$ of the fingertip, also known as capillaries number. Capillary width was defined as the distance between the widest point of the arterial branch and the venous branch. Capillary length was defined as the distance from the apex of the capillary loop to the basal region. The widest point of the arterial branch and venous branch was defined as the width of the arterial branch and the venous branch. The inner diameter of the capillaries was defined as the distance between the arterial and venous limbs measured at the same level of the capillary loop. The diameter of the capillary loop was defined as the widest distance at the apex of a capillary loop and the subpapillary vein plexus was defined as the vascular network in the basal area of the finger nailfold.

\section{Apparatus and method}

Type TR8000D micro-circulation detector (model TR1580D10001, the micro-circulation detection mirror unit is TR15SXJG001) was used. All tests were independently completed by the same senior rheumatologist. The morphology of the nailfold microcirculation of the subject was carefully observed, a clear image taken, and the diameter of the arterial branch, the diameter of the venous branch, the density of the capillary, the loop apex diameter, and the flow velocity of the capillary in the microcirculation were measured. Whether there was bleeding around the vessel, exudation, and thrombosis were also recorded and a built-in computer program calculated the final nailfold capillaroscopic scores (NFCS). A score $\geq$ 2 points was defined as abnormal $(2 \leq$ points $<4$ points was classed as a mild abnormality, $4 \leq$ points $<8$ points as moderate, and 8 or more points as severe).

\section{Laboratory methods}

Appropriate amounts of serum of all subjects were stored and kept frozen at $-80{ }^{\circ} \mathrm{C}$. ELISA was used to detect the levels of IL-17, IL- 6 and TNF- $\alpha$ in serum. The kit was purchased from eBioscience. Serum 25-hydroxyvitamin D [25 (OH) D3] was detected using a photochemical immunoassay kit (Roche Diagnostics). Weiss method was used to detect ESR, and immune scattering rate turbidimetry was used to detect CRP (reference range: 0-6mg / L). Rheumatoid factors ( $\mathrm{RF}$, reference range: 0-30 UI/ $\mathrm{mL}$ ) were determined by the latex agglutination test. Anticyclic citrullinated peptide antibodies (ACPA, reference range: $0-45 \mathrm{U} / \mathrm{mL}$ ) were determined by the enzyme linked immunosorbent assay. The detection steps were carried out in strict accordance with the instructions.

\section{Statistical analysis}

All data were analyzed using SPSS 19.0 software. Measurement data were expressed as mean \pm standard deviation $(x \pm \underline{s})$. T-test or analysis of variance was used to compare data between the two groups depending on the nature of the data. The related factors of sarcopenia were analyzed by Pearson correlation, and the risk factors of sarcopenia were analyzed by Logistic regression. $\mathrm{P}<0.05$ indicated significant difference, and all tests were two-sided.

\section{RESULTS}

\section{General comparison of RA group and healthy control group}

130 women with RA were included in the study. The course of disease was (11.83 \pm 6.82$)$ months, the age ranged from 22 to 71 years, the average was $(45.37 \pm 9.84)$ years, and the BMI was $(24.85 \pm 3.76) \mathrm{kg} / \mathrm{m}^{2}$. Compared with the healthy control group, there were no significant differences. It can be seen from Table 1 that the levels of NFCS and serum IL-17 were higher than those of the 
Table 1. Comparison of clinical data of RA and control group.

\begin{tabular}{|c|c|c|c|c|c|c|c|c|c|c|c|c|c|}
\hline Group & $\begin{array}{c}\text { Age } \\
\text { (years) }\end{array}$ & $\begin{array}{c}\text { Disease } \\
\text { course } \\
\text { (months) }\end{array}$ & $\begin{array}{c}\text { ESR } \\
(\mathrm{mm} / \mathrm{h})\end{array}$ & $\begin{array}{c}\text { CRP } \\
(\mathrm{mg} / \mathrm{L})\end{array}$ & DAS28 & $\begin{array}{c}\text { ACPA } \\
(\mathrm{U} / \mathrm{mL})\end{array}$ & $\begin{array}{c}25(\mathrm{OH}) \mathrm{D}_{3} \\
(\mathrm{ng} / \mathrm{mL})\end{array}$ & NFCS & $\begin{array}{c}\text { IL-17 } \\
(\mathrm{pg} / \mathrm{mL})\end{array}$ & $\begin{array}{c}\text { IL-6 } \\
(\mathrm{pg} / \mathrm{mL})\end{array}$ & $\begin{array}{c}\text { TNF- } \alpha \\
(\mathrm{pg} / \mathrm{mL})\end{array}$ & $\begin{array}{c}\text { BMI } \\
\left(\mathrm{kg} / \mathrm{m}^{2}\right)\end{array}$ & $\begin{array}{c}\mathrm{SMI} \\
\left(\mathrm{kg} / \mathrm{m}^{2}\right)\end{array}$ \\
\hline $\begin{array}{l}\text { RA } \\
(n=130)\end{array}$ & $\begin{array}{l}45.37 \\
\pm 9.84\end{array}$ & $\begin{array}{r}11.83 \\
\pm 6.82\end{array}$ & $\begin{array}{r}39.67 \\
\pm 12.02\end{array}$ & $\begin{array}{l}12.03 \\
\pm 4.49\end{array}$ & $\begin{array}{c}4.58 \\
\pm 1.56\end{array}$ & $\begin{array}{c}69.47 \\
\pm 39.68\end{array}$ & $\begin{array}{r}17.32 \\
\pm 6.24\end{array}$ & $\begin{array}{c}5.36 \\
\pm 2.36\end{array}$ & $\begin{array}{l}29.93 \\
\pm 5.54\end{array}$ & $\begin{array}{l}76.25 \\
\pm 7.96\end{array}$ & $\begin{array}{c}5.57 \\
\pm 0.93\end{array}$ & $\begin{array}{l}24.85 \\
\pm 3.76\end{array}$ & $\begin{array}{c}5.57 \\
\pm 0.93\end{array}$ \\
\hline $\begin{array}{l}\text { control } \\
(\mathrm{n}=80)\end{array}$ & $\begin{array}{c}46.58 \\
\pm 12.37\end{array}$ & - & $\begin{array}{l}20.28 \\
\pm 6.15\end{array}$ & $\begin{array}{r}4.34 \\
\pm 1.21\end{array}$ & - & - & $\begin{array}{l}22.53 \\
\pm 5.56\end{array}$ & $\begin{array}{c}1.34 \\
\pm 0.57\end{array}$ & $\begin{array}{c}8.17 \\
\pm 1.92\end{array}$ & - & - & $\begin{array}{l}23.42 \\
\pm 3.08\end{array}$ & $\begin{array}{c}7.12 \\
\pm 1.03\end{array}$ \\
\hline$t$-value & -0.073 & - & 14.511 & 5.120 & - & - & -4.886 & 13.612 & 87.635 & - & - & 0.19 & -3.792 \\
\hline$P$ & 0.918 & - & $<0.001$ & $<0.001$ & - & - & $<0.001$ & $<0.001$ & $<0.001$ & - & - & 0.786 & $<0.001$ \\
\hline
\end{tabular}

Table 2. Comparison of clinical data of sarcopenia group and non-sarcopenia group.

\begin{tabular}{|c|c|c|c|c|c|c|c|c|c|c|c|c|c|}
\hline Group & $\begin{array}{c}\text { Age } \\
\text { (years) }\end{array}$ & $\begin{array}{c}\text { Disease } \\
\text { course } \\
\text { (months) }\end{array}$ & $\begin{array}{c}\text { ESR } \\
(\mathrm{mm} / \mathrm{h})\end{array}$ & $\begin{array}{c}\text { CRP } \\
(\mathrm{mg} / \mathrm{L})\end{array}$ & DAS28 & $\begin{array}{l}\text { ACPA } \\
(\mathrm{U} / \mathrm{ml})\end{array}$ & $\begin{array}{c}25(\mathrm{OH}) \mathrm{D}_{3} \\
(\mathrm{ng} / \mathrm{ml})\end{array}$ & NFCS & $\begin{array}{c}\text { IL-17 } \\
(\mathrm{pg} / \mathrm{mL})\end{array}$ & $\begin{array}{c}\text { IL-6 } \\
(\mathrm{pg} / \mathrm{mL})\end{array}$ & $\begin{array}{c}\text { TNF- } \alpha \\
(\mathrm{pg} / \mathrm{mL})\end{array}$ & $\begin{array}{c}\mathrm{BMI} \\
\left(\mathrm{Kg} / \mathrm{m}^{2}\right)\end{array}$ & $\begin{array}{c}\mathrm{SMI} \\
\left(\mathrm{Kg} / \mathrm{m}^{2}\right)\end{array}$ \\
\hline $\begin{array}{l}\text { Sarcopenia } \\
(\mathrm{n}=56)\end{array}$ & $\begin{array}{l}43.33 \\
\pm 9.58\end{array}$ & $\begin{array}{r}11.15 \\
\pm 7.32\end{array}$ & $\begin{array}{c}44.33 \\
\pm 14.45\end{array}$ & $\begin{array}{l}14.95 \\
\pm 4.29\end{array}$ & $\begin{array}{c}5.81 \\
\pm 1.32\end{array}$ & $\begin{array}{c}90.58 \\
\pm 37.89\end{array}$ & $\begin{array}{l}11.54 \\
\pm 3.31\end{array}$ & $\begin{array}{c}7.63 \\
\pm 1.46\end{array}$ & $\begin{array}{l}33.54 \\
\pm 4.65\end{array}$ & $\begin{array}{l}85.26 \\
\pm 8.09\end{array}$ & $\begin{array}{l}12.98 \\
\pm 2.15\end{array}$ & $\begin{array}{l}28.76 \\
\pm 5.01\end{array}$ & $\begin{array}{c}4.68 \\
\pm 0.56\end{array}$ \\
\hline $\begin{array}{l}\text { Non- } \\
\text { sarcopenia } \\
(n=74)\end{array}$ & $\begin{array}{l}48.42 \\
\pm 9.62\end{array}$ & $\begin{array}{c}12.76 \\
\pm 7.9\end{array}$ & $\begin{array}{l}36.56 \\
\pm 9.43\end{array}$ & $\begin{array}{l}10.08 \\
\pm 3.47\end{array}$ & $\begin{array}{c}3.76 \\
\pm 1.05\end{array}$ & $\begin{array}{c}55.38 \\
\pm 24.65\end{array}$ & $\begin{array}{l}21.17 \\
\pm 4.51\end{array}$ & $\begin{array}{c}3.75 \\
\pm 1.06\end{array}$ & $\begin{array}{l}27.52 \\
\pm 4.76\end{array}$ & $\begin{array}{l}54.27 \\
\pm 6.26\end{array}$ & $\begin{array}{c}8.39 \\
\pm 1.55\end{array}$ & $\begin{array}{l}21.37 \\
\pm 3.69\end{array}$ & $\begin{array}{c}6.17 \\
\pm 0.57\end{array}$ \\
\hline$t$-value & -2.010 & 0.915 & 2.526 & 4.826 & 1.583 & 3.713 & -8.964 & 9.849 & 4.843 & 8.694 & 3.254 & 2.573 & -9.916 \\
\hline$P$ & 0.046 & 0.218 & 0.014 & 0.001 & $<0.001$ & $<0.001$ & $<0.001$ & $<0.001$ & $<0.001$ & $<0.001$ & $<0.001$ & $<0.001$ & $<0.001$ \\
\hline
\end{tabular}

Table 3. Logistic regression analysis of the associated factors of sarcopenia in female RA patients.

\begin{tabular}{lcccccc}
\hline & B & SE & Wals & $P$ & OR & $95 \%$ CI \\
\hline IL-17 & 0.416 & 0.212 & 3.862 & 0.049 & 1.516 & $1.001,2.297$ \\
DAS28 & -0.103 & 0.416 & 0.061 & 0.804 & 0.902 & $0.399,2.040$ \\
NFCS & 1.252 & 0.411 & 9.272 & 0.002 & 3.497 & $1.562,7.892$ \\
CRP & 0.384 & 0.210 & 3.682 & 0.045 & 1.469 & $0.992,2.175$ \\
BMI & 0.167 & 0.177 & 0.896 & 0.344 & 1.182 & $0.836,1.671$ \\
25(OH)D & -0.936 & 0.389 & 5.784 & 0.016 & 0.392 & $0.183,0.841$ \\
\hline
\end{tabular}

control group, and serum $25(\mathrm{OH})$ D3 and SMI were lower than those of the control group.

\section{General comparison after grouping by sarcopenia}

There were 56 cases (43.1\%) of sarcopenia in RA patients, the age of which was $43.33 \pm 9.58$ years, which was lower than that of the non-sarcopenia group (48.42 \pm 9.62 years); SMI was $4.68 \pm 0.56 \mathrm{~kg} / \mathrm{m}^{2}$, which was lower than that of the non-sarcopenia group $\left(6.17 \pm 0.57 \mathrm{~kg} / \mathrm{m}^{2}\right)$. As can be seen from Table 2, the ESR, CRP, DAS28, ACPA, NFCS, IL-6, IL-17, TNF- $\alpha$, and BMI of patients with sarcopenia were higher than those without sarcopenia, and the differences were statistically significant. The $25(\mathrm{OH})$ D3 level in patients with sarcopenia was lower than that of the non-sarcopenia group, and the difference was statistically significant $(\mathrm{t}=-8.964, P<0.001)$.

\section{Correlation analysis between SMI and serum $25(\mathrm{OH})$ D3, IL-17 levels and NFCS}

Pearson correlation analysis found that SMI was positively correlated with $25(\mathrm{OH}) \mathrm{D} 3(\mathrm{r}=0.693, P<0.001)$, and the two remained positively correlated after adjustment for age, disease duration, and DAS28 ( $r=0.515$, $P<0.001$ ) (Fig. 1). SMI was negatively correlated with IL-17 ( $\mathrm{r}=-0.597, P<0.001)$, and the two still had a negative correlation after correction $(r=-0.468, P<0.001)$, as shown in Fig. 2. SMI was negatively correlated with NFCS ( $r=-0.819, P<0.001)$, and the two still had a negative correlation after correction $(\mathrm{r}=-0.229, P=0.009)$, as shown in Fig. 3.

\section{Analysis of risk factors for sarcopenia in RA female patients}

Using the occurrence of sarcopenia as a dependent variable ( $\operatorname{sarcopenia}=1$; non-sarcopenia $=0$ ), and age, DAS28, CRP, course of disease, BMI, IL-17, IL-6, TNF- $\alpha$, 


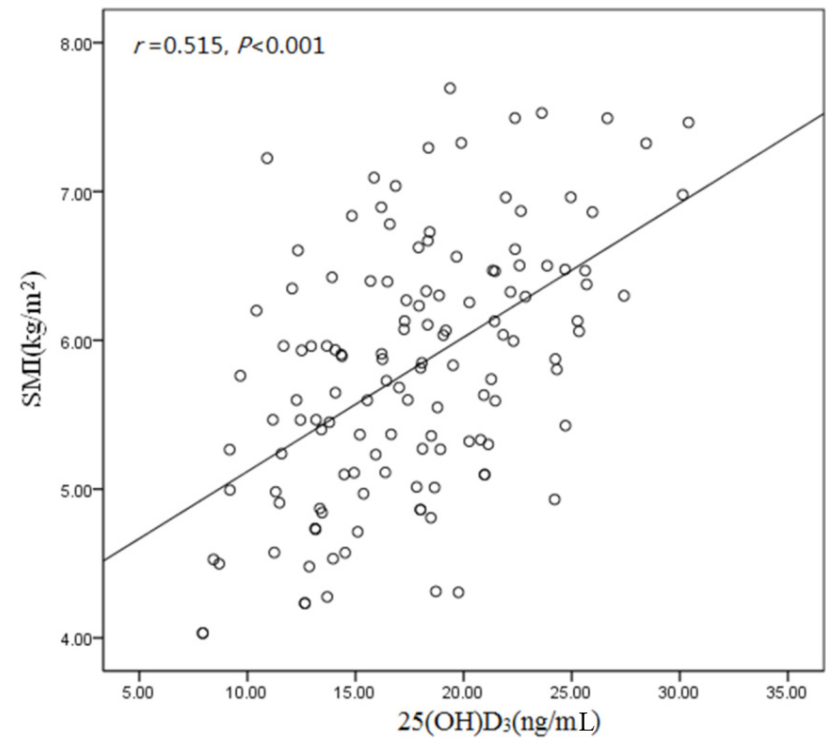

Fig. 1. Correlation between SMI and serum $25(\mathrm{OH}) \mathrm{D}_{3}$ Scatter plot indicates a positive correlation between SMI and serum 25 $(\mathrm{OH})$ D3 levels $(\mathrm{r}=0.515, P<0.001)$.

NFCS, etc. as covariates in logistic regression analysis: serum $25(\mathrm{OH}) \mathrm{D} 3$ was a protective factor for sarcopenia ( $\mathrm{OR}=0.392, P=0.016)$; IL-17, CRP, NFCS were risk factors for sarcopenia $(\mathrm{OR}=1.516, P=0.049$; $\mathrm{OR}=1.469, P=0.045$; $\mathrm{OR}=3.497, P=0.002)($ Table 3$)$.

\section{DISCUSSION}

Sarcopenia is a syndrome associated with loss of skeletal muscle mass and decreased muscle strength, which in turn increases physical disability, decreases quality of life, and increases the risk of adverse events such as death. Aging is closely related to it and, at the same time, endocrine diseases, neurodegenerative diseases, inflammatory diseases, cachexia and other chronic diseases and causes will accelerate muscle loss. In 2010, the European Working Group on sarcopenia reached a consensus classifying aging and other factors as the cause of sarcopenia in the elderly ${ }^{7}$. RA is a chronic inflammatory autoimmune disease, which causes not only bone and joint damage and structural damage, but also leads to the development of sarcopenia in $23.9 \%$ of patients ${ }^{1}$. Our study found that the incidence of sarcopenia in female RA patients was $43.1 \%$, which is similar to the results described by Doğan et al. ${ }^{8}$.

In this study, the CRP, IL-6, TNF- $\alpha$, IL-17, and ACPA titers in RA with sarcopenia were significantly higher than those in the control group. Doğan et al. ${ }^{8}$ found that IL-6 and TNF- $\alpha$ play an important role in the decomposition of the skeletal muscle system. Inflammatory factors such as TNF- $\alpha$ can promote protein degradation in skeletal muscle cells by activating the ubiquitin-proteasome pathway, leading to the occurrence of sarcopenia, and high levels of CRP are also associated with sarcopenia ${ }^{9}$. In RA patients, during the pathological process of arthritis, cartilage destruction, joint deformity, etc., IL-17 stimulates vascular endothelial cells to secrete vascular endothelial

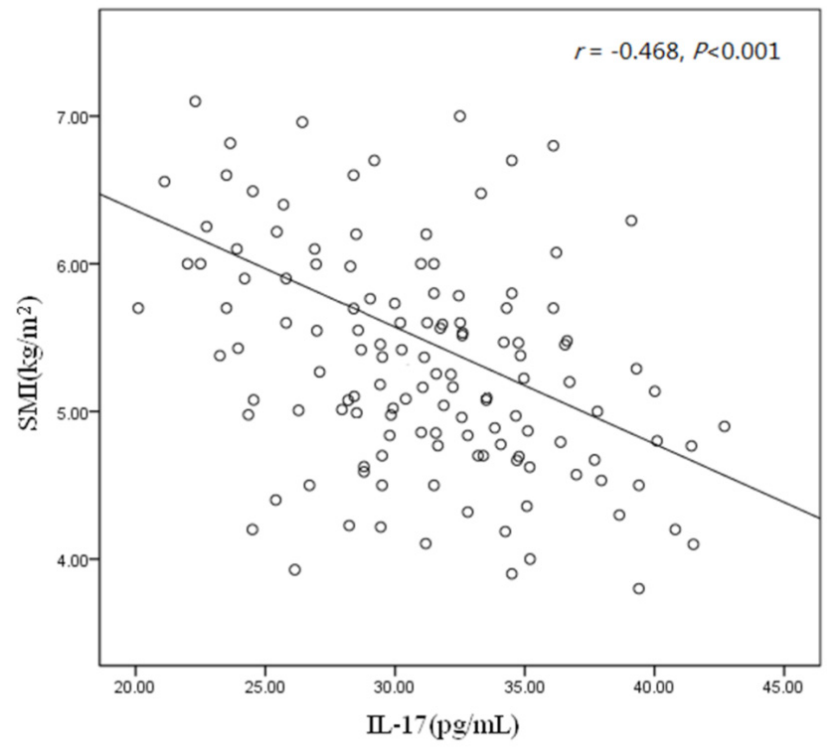

Fig. 2. Correlation between SMI and serum IL-17. Scatter plot indicates a negative correlation between SMI and serum IL-17 levels $(\mathrm{r}=-0.468, P<0.001)$.

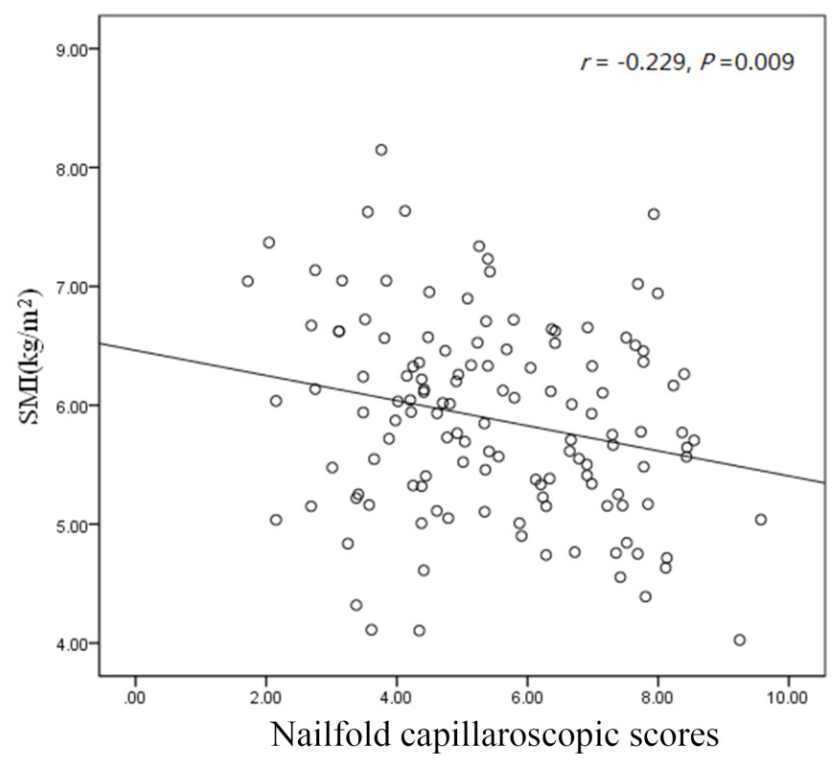

Fig. 3. Correlation between SMI and nailfold capillaroscopic score. Scatter plot indicates a negative correlation between SMI and nailfold microcirculation score $(\mathrm{r}=-0.229, P=0.009)$.

growth factor and promote the formation of blood vessels, which induces synovial cells and chondrocytes to express metalloproteinases, breaking down proteoglycan molecules and destroying cartilage tissues ${ }^{10}$. Tada et al. ${ }^{11}$ found that high levels of metalloproteinases are associated with RA with sarcopenia, but the specific mechanism is unknown. It has been indicated ${ }^{12}$ that autophagy is imbalanced in synovial cells, osteoclasts, T, B lymphocytes, and plasma cells in rheumatoid arthritis. The level of autophagy is significantly correlated with the level of anti-CCP antibodies. Autophagy helps to stabilize the intracellular environment under physiological conditions, but in- 
creased autophagy promotes autophagic cell death and disease progression, and can also cause skeletal muscle atrophy. Other sarcopenia-related factors include bone erosion, joint deformities and dysfunction, and $25(\mathrm{OH})$ D3 deficiency ${ }^{13}$.

In our study, the serum $25(\mathrm{OH}) \mathrm{D} 3$ of female patients with RA was $(17.32 \pm 6.24) \mathrm{ng} / \mathrm{mL}$, which was significantly lower than that of the healthy control group, and the level of $25(\mathrm{OH}) \mathrm{D} 3$ in patients with RA and sarcopenia was also lower than that of patients with non-sarcopenia RA. $25(\mathrm{OH})$ D3 can directly affect bones by regulating calcium and phosphorus metabolism, and can also bind to vitamin D receptors in skeletal muscle cells to play a role in regulating muscle mass and strength. Liu et al. ${ }^{14}$ conducted a study on middle-aged and elderly people in China, and it was found that a decrease in $25(\mathrm{OH}) \mathrm{D} 3$ levels was closely related to a decrease in muscle mass in the extremities. At the same time, Mastaglia et al. ${ }^{15}$ found that $25(\mathrm{OH}) \mathrm{D} 3$ had a significant effect on skeletal muscle function and muscle strength, and was positively correlated with walking pace, standing balance ability, grip strength, and muscle strength in the lower limbs. Vitamin D deficiency is an important factor for secondary sarcopenia in RA. At the same time, research ${ }^{16}$ has also found that serum $25(\mathrm{OH}) \mathrm{D} 3$ levels in RA patients are closely related to microvascular function, vitamin D deficiency and blood flow-mediated vasodilation, and is independently related to neck carotid intima-medial thickness. Maintaining normal serum $25(\mathrm{OH})$ D3 levels plays an important role in vascular function in patients with RA, and may also have a role in the prevention or treatment of sarcopenia ${ }^{17}$.

Vitamin D binds specific receptors to regulate bone calcium and phosphorus metabolism and thus affects the occurrence and development of osteoporosis ${ }^{18}$. At the same time, vitamin D is a hormone-like substance, which affects the synthesis of cytokines such as IL-17 through dendritic cells and $\mathrm{T}$ and $\mathrm{B}$ lymphocytes. In our study, the level of IL-17 in RA patients was increased, while the level of IL-17 in RA patients with sarcopenia was higher than that in patients without sarcopenia. IL-6 and IL-17 are important cytokines secreted by Th17, and are closely related to the aging of vascular endothelial cells, decreased vasodilation, reduced elasticity of arteries, vascular aging and circulatory disorders ${ }^{19}$. TNF- $\alpha$ can also activate vascular endothelial cells through the NF- $\mathrm{B}$ signaling pathway, and then express a variety of cytokines and adhesion molecules, triggering inflammatory leukocyte infiltration, inducing apoptosis of endothelial cells, and accelerating vascular aging ${ }^{20}$. Due to the combination of the multiple mechanisms mentioned above, RA is associated with wide range of microcirculatory abnormalities, which can be detected by nailfold capillary microscopy ${ }^{21}$. Our study found that the nailfold microcirculation score of female RA patients was significantly higher than that of healthy controls, while that of RA patients with sarcopenia was higher than that of those without sarcopenia. Logistic regression analysis found that an increased nailfold microcirculation score was a risk factor for RA sarcopenia ( $\mathrm{OR}=3.497, P=0.002)$. The above-mentioned multiple inflammatory factors were involved in the connection between RA sarcopenia and microcirculation disorders, but the specific mechanism needs further research in the future.

Limitations are present in this study: the increasing age of patients, aging of tissues in organs, precapillary factors such as arteriosclerosis, cardiac function, and changes in connective tissues around blood vessels will all affect microcirculation. In addition, methotrexate is the cornerstone drug for RA treatment, which can reduce the activity of pro-inflammatory factors and improve sarcopenia. The mechanism may be related to improving insulin resistance and regulating dyslipidemia, indirectly affecting energy metabolism ${ }^{22}$. However, it has been found that methotrexate can affect vascular endothelial function, which in turn affects the state of microcirculation and influences the results of the study to a certain extent ${ }^{23}$.

\section{CONCLUSION}

RA with sarcopenia is not uncommon and is closely related to microcirculation disorders. Increased nailfold microcirculation scores are a risk factor for sarcopenia. Decreased serum 25 (OH) D3 levels and increased IL-17 are associated with sarcopenia but whether this relationship mediates RA microcirculation abnormalities and the development of sarcopenia requires further study.

Acknowledgement: Authors would like to thank Dr Jan Vindis, Head of Biochemistry Department of Faculty Hospital Trencin for his technical and personal support during this study.

Author contributions: LZ, DM: conceived and designed the study, manuscript writing; LZ, QZ: performed the experiments and analyzed the date; All authors read and approved the final manuscript.

Conflict of interest statement: The authors declare that they have no conflict of interest.

Compliance with ethical standards: This study was approved by the ethics committee of Shengli Oilfield Central Hospital (Dongying, China). Written informed consent was obtained from all participants.

\section{REFERENCES}

1. Targowski T. Sarcopaenia and rheumatoid arthritis. Reumatologia 2017;55(2):84-7.

2. Di Monaco M, Vallero F, Di Monaco R, Tappero R. Prevalence of sarcopenia and its association with osteoporosis in 313 older women following a hip fracture. Arch Gerontol Geriatr 2011;52(1):71-4.

3. Graceffa D, Amorosi B, Maiani E, Bonifati C, Chimenti MS, Perricone $\mathrm{R}, \mathrm{Di}$ Carlo A. Capillaroscopy in psoriatic and rheumatoid arthritis: a useful tool for differential diagnosis. Arthritis 2013;2013:957480.

4. Aletaha D, Neogi T, Silman AJ, Funovits J, Felson DT, Bingham III CO, Birnbaum NS, Burmester GR, Bykerk VP, Cohen MD, Combe B. 2010 rheumatoid arthritis classification criteria: an American College of Rheumatology/European League Against Rheumatism collaborative initiative. Ann Rheum Dis 2010;69(9):1580-8.

5. Chen LK, Liu LK, Woo J, Assantachai P, Auyeung TW, Bahyah KS, Chou 
MY, Chen LY, Hsu PS, Krairit O, Lee JS. Sarcopenia in Asia: consensus report of the Asian Working Group for Sarcopenia. J Am Med Dir Assoc 2014;15(2):95-101.

6. Ingegnoli F, Gualtierotti R, Lubatti C, Zahalkova L, Meani L, Boracchi $P$, Zeni S, Fantini F. Feasibility of different capillaroscopic measures for identifying nailfold microvascular alterations. Semin Arthritis Rheum 2009; 38(4):289-95.

7. Cruz-Jentoft AJ, Baeyens JP, Bauer JM, Boirie Y, Cederholm T, Landi F, Martin FC, Michel JP, Rolland Y, Schneider SM, Topinková E. Sarcopenia: European consensus on definition and diagnosis: Report of the European Working Group on Sarcopenia in Older People. Age Ageing 2010;39(4):412-23

8. Ceyhan SD, Hizmetli S, Hayta E, Kaptanoğlu E, Erselcan T, Güler E. Sarcopenia in women with rheumatoid arthritis. Eur J Rheumatol 2015;2(2):57-61.

9. Schaap LA, Pluijm SM, Deeg DJ, Visser M. Infammatory markers and loss of muscle mass (sarcopenia) and strength. Am J Med 2016;119(526):9-17.

10. Lubberts $\mathrm{E}$, Koenders MI, van den Berg WB. The role of T-cell interleukin-17 in conducting destructive arthritis:lessons from animal models. Arthritis Res Ther 2005; 7(1):29-37.

11. Tada M, Yamada Y, Mandai K, Hidaka N. Matrix metalloprotease 3 is associated with sarcopenia in rheumatoid arthritis-results from the CHIKARA study. Int J Rheum Dis 2018;21(11):1962-9.

12. Sandri Marco. Autophagy in skeletal muscle. FEBS Lett 2010;584(7):1411-16.

13. Ngeuleu A, Allali F, Medrare L, Madhi A, Rkain H, Hajjaj-Hassouni N Sarcopenia in rheumatoid arthritis: prevalence, influence of disease activity and associated factors. Rheumatol Int 2017; 37: 1015-20.

14. Liu G, Lu L, Sun Q, Ye X, Sun L, Liu X, Zong G, Jin Q, Li H, Lin X. Poor vitamin $D$ status is prospectively associated with greater muscle mass loss in middle-aged and elderly Chinese individuals. J Acad Nutr Diet 2014;114(10):1544-51.

15. Mastaglia SR, Seijo M, Muzio D, Somoza J, Nunez M, Oliveri B. Efect of vitamin $D$ nutritional status on muscle function and strength in healthy women aged over sixty five years. J Nutr Health Aging 2011; 15(5):349-54.

16. Ranganathan $P$, Khalatbari S, Yalavarthi S, Marder W, Brook R, Kaplan MJ. Vitamin D deficiency, interleukin 17, and vascular function in rheumatoid arthritis. J Rheumatol 2013; 40(9):1529-34.

17. Campins L, Camps M, Riera A, Pleguezuelos E, Yebenes JC, SerraPrat M. Oral Drugs Related with Muscle Wasting and Sarcopenia. A Review. Pharmacology 2016;99(1-2):1-8.

18. Cranney A, Weiler HA, O'Donnell S, Puil L. Summary of evidencebased review on vitamin $D$ efficacy and safety in relation to bone health. Am J Clin Nutr 2008; 88(2):513-19.

19. Shan $H$, Bai XJ, Chen XM. Angiotensin II induces endothelial cell senescence via the activation of mitogen-activated protein kinases. Cell Biochem Funct 2008;26(4):459-66.

20. Terzuoli E, Meini S, Cucchi P, Catalani C, Cialdai C, Maggi CA, Giachetti A, Ziche M, Donnini S. Antagonism of bradykinin B2 receptor prevents inflammatory responses in human endothelial cells by quenching the NF-KB pathway activation. PLoS One 2014;9(1):e84358.

21. Zaric D, Worm AM, Stahl D, Clemmensen OJ. Capillary microscopy of the nailfold in psoriatic and rheumatoid arthritis. Scand J Rheumatol 1981;10(3):249-52.

22. Ferraz-Amaro I, González-Juanatey C, López-Mejias R, RianchoZarrabeitia L, González-Gay MA. Metabolic syndrome in rheumatoid arthritis. Mediators Inflamm 2013;2013:710928.

23. Syngle V, Syngle A, Garg N, Krishan P, Verma I. Predictors of autonomic neuropathy in rheumatoid arthritis. Aulon Neurosci 2016;201:54-9. 